\title{
SOCIAL CULTURE AND PUBLIC PARTICIPATION IN THE DEVELOPMENT OF KAMPUNG KOTA: A CASE STUDY IN BANDUNG INDONESIA
}

\author{
Ana Ramdani Sari \\ Department of Architectural Education, \\ Universitas Pendidikan Indonesia, Bandung, 40154, Indonesia \\ anarsari@upi.edu
}

\begin{abstract}
Kampung Kota has been associated with slums due to its substandard living condition despite having different characteristics to slums. To improve the quality of life in Kampung Kota community, it is important to actively involve the community itself to transform Kampung Kota to better direction and to exercise democracy within urban development. The research aims to understand in what ways the community has been involved, how the community perceived their involvement, how the community wishes to be involved and in what ways community participation could be improved in transforming Mekarjaya and maximizing its social capital. The research was conducted using qualitative methodology and case study strategy. Interviews, observation, and documentary evidence are used to collect the data and to validate the data by cross-checking every information using the triangulation technique. The research finds that the community has not been actively involved in many programs and projects. It is due to the nature of the government programs that support the funding. However, most of the people; whose voices are generally represented by the head of $R T / R W$ (Community unit/neighborhood unit); are far more eager and willingly contribute to the development if they have the platform to do so. Moreover, cultural customs ingrained in the Kampung Kota community also influence how the community work together in the Kampung Kota Transformation.
\end{abstract}

\section{Keywords: Community Participation, Kampung Kota, Development}

\section{Introduction}

\subsection{Background}

The existence of slums has been a common occurrence in many cities around the world. There are 800 million people live in slums in Asia, Africa, dan Latin America in 2008, based on the UN-Habitat Report (Fox, 2014). Slums have been associated with inadequate living environments coupled with unsafe dwelling structures, overcrowding, limited access to clean water, and insufficient sanitation system and facilities (Fox, 2014).

Over the years, the government, various organizations, and the people have tried to tackle the problem by implementing various programs and projects. The roles of the local community have been proven crucial since they have the knowledge to help to identify the issues and providing solutions in various aspects. For example, projects conducted by the Asian Coalition of Community Action (ACCA) have successfully produced enumeration data dan maps to help the local community built their dream houses in Pattani, Thailand, and in Bharatpur, Nepal, even with a tight budget. They worked alongside the local people with assistance from the community architects and other related professionals (Archer et al., 2012).

Enabling the community to be actively involved in the development promotes a more democratic approach in planning practice. After all, anyone affected by the development or planning practices should be able to participate in the decision-making process (Davies, 2010). However, it is essential to distinguish the tick-boxing public participation with the one which significantly affects the outcomes (Arnstein, 1969). More than letting the community be heard, they also need to be provided with necessary information and the chance to give feedback (Davidoff, 1965). 
The same principle needs to be implemented in the improvement of slum area. In Indonesia, slum is often associated with Kampung Kota (UN-Habitat, 2003). Although they are not necessarily the same; many Kampung Kota shares similar characteristics as slum. Various measures have been implemented; however, it is still debatable whether public participation haven been reinforced properly in the process as many local communities are often aggrieved (Peters, 2009).

Community engagement in Kampung Kota is important but needs to be explored more. This research will address the issue by using the study case of Mekarjaya through the following questions:

1. How the local community perceived their participation in the Development of Kampung Kota in Mekarjaya based on their social meaning?

2. How the local community want to be involved in the Development of Kampung Kota in Mekarjaya?

3. How to improve the development Kampung Kota in Mekarjaya through public participation?

The majority of research on slums have been centered on the cause and effect of slums namely medical issues (e.g. Samba et. al. 2009; Solikhah and Fatimah, 2020), safety (e.g. Nasir, 2009; Permana, et al., 2019), and urban space quality (e.g. Nastiti, 2017; Kustiwan and Ramadhan, 2021). However, the study on public participation in slum has not yet been explored enough. Therefore, the paper aims to investigate further about the public participation in Kampung Kota who shares similar nature as slum. It serves as a new narrative of public participation in Kampung Kota of Bandung through social lens. Moreover, the research findings can be utilized to improve projects and policies of Kampung Kota improvement by empowering the local community though public participation.

The social capital derived from the relationship among Kampung Kota residents becomes a great opportunity to implement schemes and policies that involves the local community in the making. However, it is yet doubtful that the public participation has been implemented properly in the improvement of Kampung Kota, which needs to be address further.

\subsection{A Brief Literature Study: The Concept of Kampung Kota}

Terminologically, Kampung Kota can be translated as a pocket of vernacular settlement (Kampung) that is located within an urban area (Kota). Most Kampung Kota(s) have been existing for very long time, some of them even formed during the colonialization era. As the city surrounding it grows; the Kampung remains to be a housing area that holds strong traditional values eventhough when it is surrounded by urban areas. Kampung Kota in general is considered a transition society between urban and rural (Herlianto, 1986 in Widjaja, 2013). As Kampung Kota usually grow organically, most of them does not have planned infrastructures and network (Handayani, 2008).

So far, there is no exact definition about Kampung Kota. The definitions could be varied depending on the perspectives on how Kampung Kota is viewed. It is because the nature of Kampung Kota is complex and difficult to be simplified. Nonetheless, Kampung Kota can be generalized as a pocket of transitional settlements in urban area in which the residents still hold traditional values despite the rapid growth of city around it. Although there is no exact definition of Kampung Kota, it is clear that Kampung Kota is a complex matter. The characteristics can be varied from one to another. Kampung Kota can be a housing area with very narrow passageways (Peters, 2013), while others can have a large underutilised lot. In terms of social-economics condition; Kampung Kota can be an area laced with poverty while others can be well equipped with high-quality public facilities (Wahyuningsig, 2013) and even be award-winning neighbourhoods.

However, despite the variation of qualities in Kampung Kota; many of them are considered as slum area due to the poor quality of living condition. The majority of them are in poor condition economically and physically (Funo, 2013). In Bandung, out of all 19 areas identified as slum, most of them are Kampung Kota (Seputar Indonesia, 2013). The 
identification was done based on the slum criteria set by the Ministry of Housing and Public Works (P2KP, 2017); which are:

- Irregularity of urban form

- Limited access to clean water

- Poor quality of roads

- Poor sanitation

Interestingly; Kampung Kota are generally rich in terms of social capital. As Bourdieu (1998 in Handayani, 2008) described, social capital is "the aggregate of actual or potential resources which are linked to possession of durable network of more or less institutionalized relationships of mutual acquaintance or recognition". Social capital richness is particularly prominent in the interactions among Kampung people. Despite having a diverse community in terms of the social economic status and class (Silas, 1992), the people engage in many formal and informal community activities harmoniously. Neighbourhood meeting, election preparation, pengajian (qur'an recital for small to large groups), communal prayer, and slametan (communal feast) are among many activities the Kampung people indulge in (Peters, 2013). Commonly, they exhibit enthusiasm in these activities as they fundamentally still hold into traditional values. As people live in in such close proximity (Peters, 2013), Kampung people usually know each other. Therefore, if some people do not blend in with the crowd; they stick out like a sore thumb and it is easy to feel alienated in Kampung Kota. The phenomenon makes the community in Kampung Kota to be very close knitted and relatively easy to organize.

It implies the high level of social capital among Kampung Kota people (Handayani, 2008). Trust, shared vision, and mutual understanding (Cohen and Pusak in Handayani, 2008) exhibited in Kampung Kota community can lead to more efficient and effective delivery of development actions and programs.

\subsection{Limitation of Public Participation}

Even though public participation is important; it also has limitations. Therefore, it is important to understand that to what extent public participation is conducted highly varies. In one place, the decision making could be in the hands of the citizens, while in other places, the engagement can be only in the form of informing the public. It depends on the nature of the community, the goal and scale of the project, and the complexity of the relationship between stakeholders (Turner, 1979). There is also no absolute indicator on what kind of public participation is ideal (IAP2, 2015), but if a change or planning process give good outcomes that satisfy the inhabitants, it might be considered as a successful program.

\section{Methods}

The study used qualitative methodology wirh case study strategy (Yin, 2003). The strategy was chosen to analyze a social phenomenon that has not been explored, which is community participation, in a particular urban village. To ensure the data obtained was valid, the triangulation technique was used to cross-check all information from various sources. In this study, the in-depth interview was conducted to acquire primary data and get quality assurance about information gathered from the Head of Mekarjaya. The interviewees were chosen based on their active involvement of the development in Kampung Kota as well through snow-balling technique (see Table 1). Documentary evidence was collected to describe the profile area and as documentation related to Kampung Kota development programs. To capture the condition in the area and the community characteristics, unstructured direct observation is used; specially to observe the everyday occurrences around the area. The data was then compared to the existing studies and theories related to the findings about community participation and Kampung Kota.

Table 1. Respondents and Their Roles

\begin{tabular}{ccl}
\hline $\begin{array}{c}\text { Respond } \\
\text { ent }\end{array}$ & Age & Role in the Community \\
\hline TR & 55 & Head of Mekarjaya \\
\hline OO & 40 & $\begin{array}{l}\text { Community Leader (RT } \\
\text { 02/RW 03) }\end{array}$ \\
\hline JH & 29 & $\begin{array}{l}\text { Community Leader (RT } \\
\text { 01/RW 03) }\end{array}$ \\
\hline HD & 38 & Community Member \\
\hline WH & 47 & Community Member \\
\hline
\end{tabular}




\section{MN $24 \quad$ Community Member}

\section{Result and Discussion}

To give the context of the study, it is important to understand the study area and the nature of the community. Located in Bandung West Java Province Indonesia, Mekarjaya is a Kelurahan (Sub-region) located $9.3 \mathrm{~km}$ away from the city center. It comprises of $137,930 \mathrm{Ha}$ land and has a population of 16,044 people. Mekarjaya has 11 community units (Rukun Warga/RW) and 66 neighborhood units (Rukun Tetangga/RT). It comprises two types of housing; the new small gated communities scattered all over Mekarjaya and Kampung Kota. Kampung Kota within Mekarjaya have been identified to be located in RW 01, 02, 03, 08, and 11 by the Mekarjaya officials. Most of them also have been around for many decades. Dominantly, Mekarjaya's people aged between 15 and 29 also comprise $24 \%$ of the total population. It is because Mekarjaya is an urban fringe area that offers cheaper housing than the city centre; which is considerably more attractive to young people. Despite dominated by young people; there are natives of Mekarjaya who have been living in various pockets of Kampung Kota in Mekarjaya for generations.

The Ministry of Public Works has identified most of Kampung Kota area in Mekarjaya as slum which $80 \%$ of its urban form was irregular, 65\% of roads towards Kampung Kota had bad quality, and 52\% of inhabitants did not have adequate access to clean water and sanitation (P2KP, 2017). Various programs have been implemented in Kampung Kota to enhance their life aspects. Moreover, still there was unclear concern whether the community involvement and the people's needs have been properly addressed.

It is crucial to figure out underlying issues that contributed to the problem in Kampung Kota and its potentials, particularly in Mekarjaya, which is needed as an opportunity for developing the area.

\subsection{The Misconception about Kampung Kota}

To have a comprehensive discussion about Kampung Kota, it is important to understand the proper conceptualization of Kampung Kota. Kampung Kota was popularly known to as another term to describe slum. A report entitled "The Challenge of Slum", Kampung Kota was mentioned to refer to the slum in Indonesia (UN Habitat, 2003). Abrams (1996 in Widjaja, 2013) also described Kampung Kota as a slum. He further emphasized that Kampung Kota is an area that has very low income and lack of adequate infrastructure and public services. Similarly, several other scholars also stated Kampung Kota as a substandard living state (Kraussc, 1975 in Widjaja, 2013), over-crowded settlement with low quality building materials (Sutarjo, 1980 in Widjaja, 2013), and a settlement for the majority of low-income residents (Yudohusono, 1991 in Widjaja, 2013).

The Challenge of Slum report (UN Habitat, 2013) also describes slum as a physical and spatial manifestation of urban poverty areas where the inhabitants do not have access to basic amenities or properly built homes. Meanwhile, the criteria to determine as slum is still debatable (Gilbert, 2007; Njoh, 2015), it can be concluded that the main criterias are overcrowding, low quality materials, and sanitation accessibility problems (UNHabitat, 2014 in Njoh 2015). On the other hand, Njoh (2015) argued those criteria are not always applicable as the definition of slum itself is highly dependent on the community and cultural context; and those existed criteria are mainly formed around Eurocentric bias.

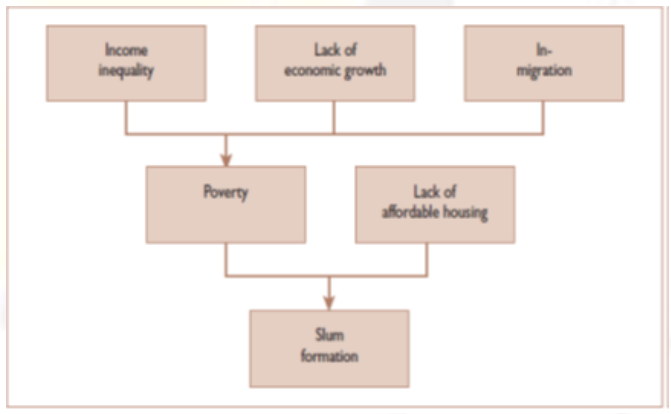

Figure 1 Factors of Slum source: UN-Habitat, 2003

Many studies have challenged the definite causes of slum. The UN-Habitat (2013) reported a number of aspects that influence the emergence of slum (see Fig 1). However, it has been argued that slum is caused by the primary factor which is the colonization aftermath (Fox, 2013) and not by a mere of rapid urbanization, economic growth, or 
poverty (Fox, 2013; Njoh, 2015). Even though Kampung Kota and slum are essentially different; both have similar factor in their origin as many Kampung Kota are also the product of colonization (Widjaja, 2013). However, Kampung Kota is fundamentally different from slum due to major diversity of socio-economic conditions and unique cultural aspect. It makes Kampung Kota does not always fit into the slum criteria that was set by the UN-Habitat (Concarplan-Sangkuriang JUDC, 1983 in Widjaja, 2013). This argument was supported by Baross (1980 in Widjaja 2013) who stated that Kampung Kota has a unique morphology which could not be simplified as a slum or squatter. Many houses in this kind of area have decent structures, well-serviced, and have legal ownership though some of them still face housing security risk (Reerink, 2011).

The stigma usually emerged because of the overcrowding that commonly happened in Kampung Kota; especially in Indonesia's major cities. In addition, as organic settlement areas that grow unplanned, there is planning controls or lot-size limitation apply to these areas, and home-owners are free to modify and expand their house, resulting in a very unique and diverse built form that is perceived as irregularity. Many residents renovate their homes to rent them out and accommodate new-commers. Often times, the residents also use cheap and easily available materials in renovating their homes before replacing them with the more durable ones (Silas, 1992). As the rent is cheap and the location is convenient, Kampung Kota attract low-income laborers and workforce who are unable to buy or rent regular housing.

The slum term could not define the complexity of Kampung Kota. The Oxford Encyclopedic Dictionary (OED) provided two definitions of slum as "an overcrowded and squalid back street, district, etc. usually in a city and inhabited by very poor people"; and "a house or a building unfit for human habitation" (Hawkins and Allen, 1991 in Gilbert, 2007). Indonesia Law No. 12011 describes slum as "a substandard living space with irregular urban patterns, high density, and inadequate and low-quality building and infrastructure". Although emphasizing the negative aspects of slum was not appropriate
(Gilbert, 2007), it was undebatable that notion was still present to this day. All in all, the negative nuance that is associated to both slum and Kampung Kota could be detrimental the development in the area. It would further segregate the area and bring despair for the residents (Gilbert, 2007). Afterall, even though being associated with negative connotation, both still play a crucial role in the city structure, and provide affordable homes and self-help housing for many people (Gilber, 2007). Rather than eliminating them entirely, its is more appropriate to address the issue and empower the people to improve their quality of life while still maintaining the role and existence of the Kampung Kota.

\subsection{The Role of Kampung Kota Community in the Development}

The community has always played an important role in planning practice and development. It also has been a common conception that those who were affected by a decision has to be involved in the decisionmaking process (Davies, 2010). However, public participation is very dependent on its effectivity on the system (Turner, 1979). It also depends on the nature of development itself. There are two forms of participation in Kampung Kota, which are informal and formal. The informal activities are the one that initiated and held by the community. These are the following examples of these activities:

\section{- Kerja Bakti/Community Work}

Kerja Bakti, which also known as gotongroyong (Armor, 1986), is a communal work organized by RT and RW that encourages all of residents' participation. The goal of this activity is ensuring cleanliness and maintaining the area in a good state. This activity varies and planned according to the community needs, namely, urban farming, cleaning, or building public facilities. RT and RW usually provide a fixed schedule for this work, or it could happen during in public holidays which are planned at a community meeting. This activities are also common in other areas especially in rural areas.

\section{- Musyawarah/Community Meeting} Musyawarah/Community Meeting is usually done in RT and RW level and led by the heads of the neighborhood units. 
What becomes the topics usually are discussed together; ranging from the schedule of kerja bakti, the community programs, to the safety and health measures for the neighborhood. This activity has been implemented since long time ago and still practiced until this modern era, especially in Kampung Kota (Kawamura, 2011).

\section{- Cultural Customs in Kampung Kota}

Interestingly, many activities that seemingly unrelated to the development also contribute greatly. In Kampung Kota, activities like Qur'an Recital, lottery club, and a potluck become the platform to discuss many issues about the neighbourhood. Sometimes, the ideas or initiatives comes from this type of activities. Without these activities, it would be hard to organize the crowd and to inform them in a comfortable atmosphere. It is easier to spread the words and coordinate this way as many residents in Kampung Kota either do not have time to attend the fixed schedule of community meeting or they feel intimidated by the formal setting, especially if government agencies are involved.

The formal activities were usually delivered by various governmental agencies at every level, such as the Ministry of Public Works, the City Government or the regional authorities, as described in the following examples:

\section{- Program Nasional Pemberdayaan} Masyarakat (PNPM)/ Urban Community-Driven Development Program

Urban CDD (World Bank, 2013) is a national government initiative to empower marginalized citizens reside in slums areas by providing a fund to improve their living conditions. The community are required to pan and execute any programs to the betterment of their neighborhood using the fund and report how the fund was used to the government. This program was started in 1999 with a different name (Proyek Penanggulangan Kemiskinan di Perkotaan (P2KP)/Urban Poverty Project (UPP)) and was applied to whole areas in Indonesia. The funding source itself came from the World Bank as a loan. In 2015, the program was replaced by the KOTAKU program that will be discussed further below.

- Program Inovasi Pembangunan dan Pemberdayaan Kewilayahan (PIPPK)/ Regional Empowerment and Development Innovation Program $P I P P K$ is a program launched by Bandung city government that was started in 2016 and aimed to decentralize the development of all $R T / R W_{\mathrm{s}}$ all over Bandung (Miftah, 2017). Similar to Urban CDD, the community decides what to do with the fund. However the difference is that, in $P I P P K$, is the community was involved in planning process, but the city hire outsourced workers to execute the plan.

- Kota tanpa Kumuh (KOTAKU)/National Slum Upgrading Program (NSUP)

KOTAKU is a national initiative that replaced P2KP and was started in 2016 (Ditjen Cipta Karya, 2017). The goal is to improve the infrastructures in a slum area and reduce the percentage of slums in urban areas. The first stage of the program is to identify the problems by implementing enumeration and mapping led by local NGOs. Based on the enumeration and the mapping; the programs are planned to improve the living condition of slum areas by collaborating with the local communities, with the local NGOs as the facilitator. The program is gradually implemented across Indonesia and has started in Bandung since 2018 (Ditjen Cipta Karya, 2017). As most of Kampung Kota are identified as a slum, the program affects the development of Kampung Kota.

The participation of Kampung Kota community is important, however it has not been done appropriately so far. As it has to be done continuously for a long time; the urban transformation in Kampung Kota needs local knowledge and is done the people itself. (Turner, 1976). A lot of cases have shown that dissociation of community role in Kampung Kota could lead to catastrophe. For instance, a similar program named Kampung Improvement Program (KIP) was implemented at Bandung in 1980 and only lasted for a few years before it was terminated (Widjaja, 2013). The low participation of the 
community in the program was the reason as the program adopted the top-down approach. As the result, the community of Kampung Kota was indifferent and the infrastructures only lasted for a short time as there was no one responsible to maintain them (Ditjen Cipta Karya, 1982 in Widjaja, 2013).

\subsection{The Community Participation in the Development of Kampung Kota in Mekarjaya.}

According to interviews with the residents, community participation in Mekarjaya can be divided into two types: informal participation and formal participation. In informal participation, all interviewees agreed that residents often participate in Kerja Bakti. Kerja Bakti activities include cleaning, planting, landscaping or construction works. However, kerja bakti is not a routine activity and the involvement is completely voluntary. On the other hand, participation in $R T / R W$ level community meetings has different results. Community leaders agreed that most residents attended the meeting, and some of them did not actively participate. Some community members explained that they occasionally attend meetings that suit their free time, while others claimed that they always present at the meeting. However, those who admitted not actively involved in any other development projects other than Kerja Bakti said that it was because their work requires them to be away from home most of the time

Formally, the community usually participates in various government programs. One of the most famous programs implemented in Mekarjaya is PIPPK. As mentioned above, $P I P P K$ is a government initiative of Bandung City, which aims to strengthen the improvement of all RT and RW in Bandung. The plan is the result of Bandung's decentralization and is coordinated by Kelurahan. The formal meeting was chaired by Kelurahan. Representatives of RT and RW attended the meeting as representatives of the community media to provide comments on the ongoing plan. However, the decision that should be made is entirely up to the authorities. The execution of these plans is also carried out through outsourced workers, without community intervention.
$P N P M /$ Urban CDD is different from the previous programs mentioned above. It has received more support from community leaders and members. Community members

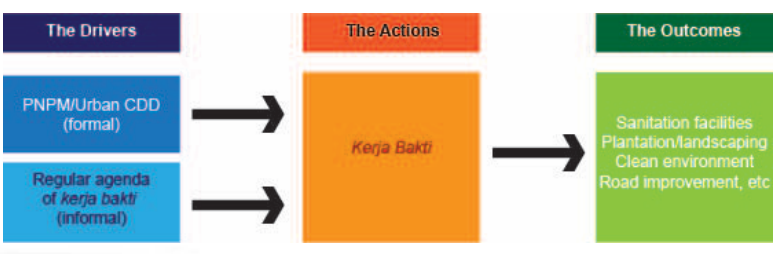

Figure 2 The relation between PNPM and kerja bakti

(such as RT and RW heads) explained that the plan helped the community to provide water for themselves through kerja bakti (see Figure 2). Regardless of the limited funds, the community voluntarily pays the balance. Since it is executed by community members, construction costs can be reduced. However, this program was discontinued in 2013 and was replaced by another program called KOTAKU. As the plan relied more on local NGOs, none of the interviewees could give a sufficient explanation; the appointment process was unclear.

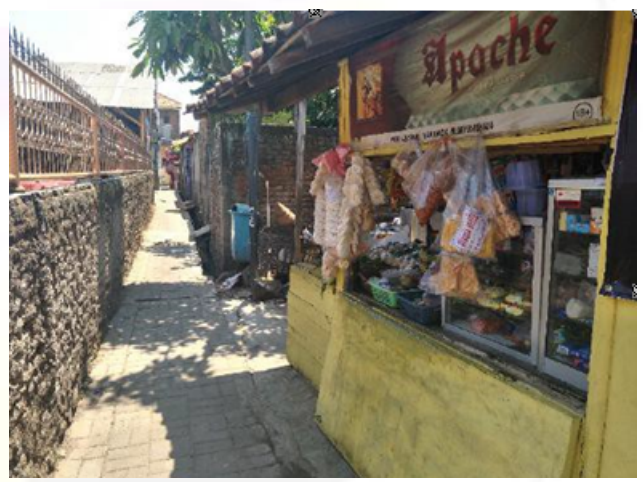

Figure 3 Warung/Makeshift Store in Alleway

There is an implication shown that the participation in informal activities was greater than the formal one (sometimes an informal activity could be as a part of a formal program (see see Figure 2)). All in all, the respondents agreed that they intensely interacted with other community members in various ways, such as kerja bakti, casual conversation in the alleyway or warung, and in communal prayer at the mosque (see fig. 5. Just like in many other Kampung area, residents who did not participate in the communal activities were often alienated, 
whether intentionally or unintentionally, by other community members (Peters, 2013). It encourages them to participate, in fear of being seen as unable to blend in. Through this dynamic, the role of social capital that is reflected in the social interaction within the community.

In formal programs, the community leaders agreed that the community showed more attention and enthusiasm in the PNPM program. In $P I P P K$, the participation was more finite and some of the community members could not directly voice out their opinion in the Kelurahan meeting. Because the implementation of PIPPK was controlled by the Kelurahan, community leaders noted a similar notion. They thought that the development could have been better if the community was directly involved, both in the planning stage and in the delivery. The people acted indifferent and less participated as actively due to see the fact that they have not been involved in the program.

\subsection{Contributing Factors in the Public Participation of Kampung Kota Development}

Despite having intense social interaction, high social capital and communal activities, it is clear that the community members are not satisfied about their involvement in the development. The residents stated that they are usually notified through mailed notification, however there is no follow-up to it. Sometimes, when some of the members tried to give their opinions, they are not heard properly. Interestingly, the residents have different views on how they were engaged. While the residents claimed they their involvement is very limited; the community leaders, especially the head of Mekarjaya, stated that the community members participate actively in the decision-making process. There were some factors identified to be contributed in community participation. Explanations were below.

\section{- Financial Stability and Jobs}

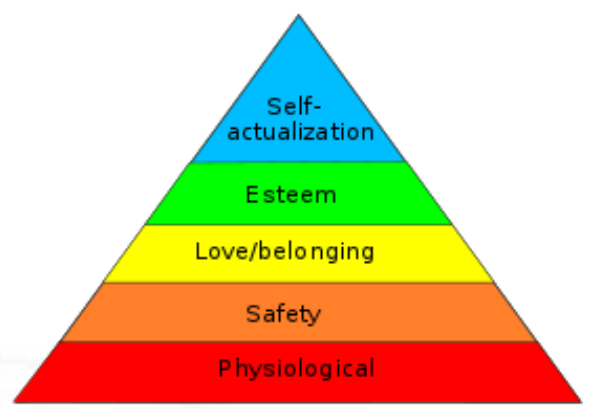

Figure 4 Maslow's (1943) Hierarchy of Needs The most glaring factor determining the level of public participation is the economy levels and jobs in the community. There is almost a consensus among the community leaders and members that people who have lowincome and unstable jobs tend to be more passive when it comes to participating in community activities. It is due to their unusual working hours and demand that makes them unable to find free time to do anything else. This phenomenon aligns with Maslow's hierarchy of needs (1943), which explain why people who have not met their physiological needs often do not feel a strong desire to achieve other needs in higher hierarchical level of needs. On the other side, people who came from more fortunate financial background have more option to participate in community activities, because their basic needs for shelter and food have been met. They can contribute the development of Mekarjaya by pitching in some fund, or working in kerja bakti. Some of them go out of their way to help organizing the event. Nevertheless, there are also other factors to consider, such as awareness and education level. The results are similar to a study done by Handayani (2010). The residents of Kampung Kota who are accustomed to be in lower income group do not have urgency to improve their living environment as long as they can afford to eat and live.

- The Role of Community Leaders

The heads RT and RW are an important factor in this scenario. In formal programs like $P I P P K$, not all Mekarjaya residents were unable to attend the meeting held in Kelurahan. In order to express their 
wishes, community members rely on community leaders (the head of $R T / R W$ ) to represent them. However, it does not always work as intended. It is up to their individual willingness to come and attend the meeting. A community leader stated that although some people may not be able to participate due to unforeseen circumstances; another reason is that some community leaders are loweducated and closeted, which also affects their judgment on development. In some cases, the heads in some RT and RW also intentionally did not participate if they see a conflicting value and interest with other stakeholders and government officials. With no one representing the residents in these particular neighborhood units, it is simply difficult for the community members to give their aspirations. In addition, other community leaders claimed that many community members are reluctant to take the initiative because they think it is rude to cross the power boundaries of community leaders.

- The Political Nature of Kampung Kota Since Indonesia adopts decentralized governance, the formal plan implemented in Mekarjaya has a different nature, depending on the authority that administers it. However, there are evidences that indicate the lack of coordination between the authorities. There are still individual agendas that undermine the implementation of the plan. For example, to quote the head of Mekarjaya:

"I cannot say anything [about KOTAKU], the government agency delegated the tasks to someone I do not know. Same with PNPM too, it was directly from the central government" (TR, 55, the Head of Mekarjaya) On the contrary, the head of Kelurahan Mekarjaya seems to be more supportive of PIPPK because they can directly control activities and projects, while community leaders in lower level (the heads of RT and RW) prefer projects such as PNPM because the national government directly provides funds to RT and RW without any direct intervention from Kelurahan. On the other hand, the more recent KOTAKU project that has been disclosed to community leaders; similar results are also faced. Even if it has not yet been implemented fully; the enumeration of the program is mainly the responsibility of local NGOs without any interference from Kelurahan or RTs and RWs. Therefore, they appeared to be less enthusiastic and supportive.

\subsection{The Community Expectations of the Public Engagement in the Kampung Kota Development in Mekarjaya}

Although the community was aware of the improvements in their community, the results clearly showed that it did not meet their expectations.

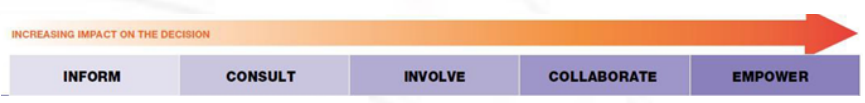

Figure 5 Community Participation Spectrum source: IAP2, 2015

The community leaders explained that the current PIPPK and other programs do not allow the public to fully participate, resulting in low community participation. Although community members were eager to participate, they did not provide a platform and enough information to participate. Especially when comparing $P I P P K$ and $P N P M$, two of the respondents gave similar statements:

"If we were given more opportunity, the community members usually will not only participate in the meeting and kerja bakti, some who have stable income often pitch in the budget. Let's say, if we only have the fund to build $100 \mathrm{~m}$ road, we can expand it to 300 meters as we do it ourselves without paying a contractor. With the financial support from the people, the budget can get even lower." (OO, 40, and JH, 29, Head of RT 02 and RW $03)$ In addition, the community members also highlight that the improvements that have been done are not so necessary. $\mathrm{JH}$ and $\mathrm{MN}$, who live in the same neighborhood, said:

"We are thankful that Kelurahan [officials] planting some plants and makes the roadside prettier. But that is not what we need. We need communal septic tank and public toilets. Many of us still use riverside to do our 'business "' (MN, 24, Resident)

Other interviewees, who live in different area said that the community needs a sports 
facility and a playground. However, to execute similar programs, it is important to improve the coordination first between the community leaders and Kelurahan to obtain better support from all stakeholders and eventually improve the condition in Kampung Kota.

\subsection{How to Plan a Well-integrated Policy}

There are different spectrum and levels of public participation (Arnstein, 1969 and IAP 2, 2015). It has been used as a guideline for how communities should participate in the planning process in modern planning practices. The Kampung Kota community in Mekarjaya has been provided opportunities and platform to develop their neighborhood. However, public participation is still not up to expectation and needs to be improved. The degree of public participation in Mekarjaya has different results depending on the operation of the project.

The past program, like $P N P M$ have achieved the delegated power level in Arnstein's Participation Ladder (1969) and the level of empowerment in IAP2's Public Participation Spectrum (2015) (see Figure 5).

Although the community's funding is limited, they have almost full control in what they want to do. They could determine their needs and priority for the community within the budget. However, execution is very dependent on the $R T / R W$ leaders. Sometimes, the project is more sporadic and small-scaled as well. If Kelurahan can be more involved in monitoring the performance of each $R T / R W \mathrm{~s}$ and leading joint projects across RTs and RWs, the results will be even better. After the end of the project, the evaluation is conducive to the improvement of future projects.

PIPPK is placed at a different level and spectrum, according to the views of the community. Public participation level in this program could be categorized as "consultation" at best and "information" at worst, but it has not been effectively implemented. There are opportunities to put forward ideas, but the final decision still depends on authority. However, PIPPK also contributed to the greater impact of urban employment issues. Due to the outsourcing of builders, cleaning staff, and manual labourers; the program employed many unemployed residents throughout the
city.The shortcomings of the aforementioned programs can be beneficial for input of the ongoing KOTAKU program or other upcoming programs. However, it should be noted that KOTAKU involves local NGOs in leading the enumeration process and facilitating the residents in mapping their needs. Therefore, participating NGOs should truly speak on behalf of the local community and address the community's needs appropriately to prevent any conflict of interests/misconduct

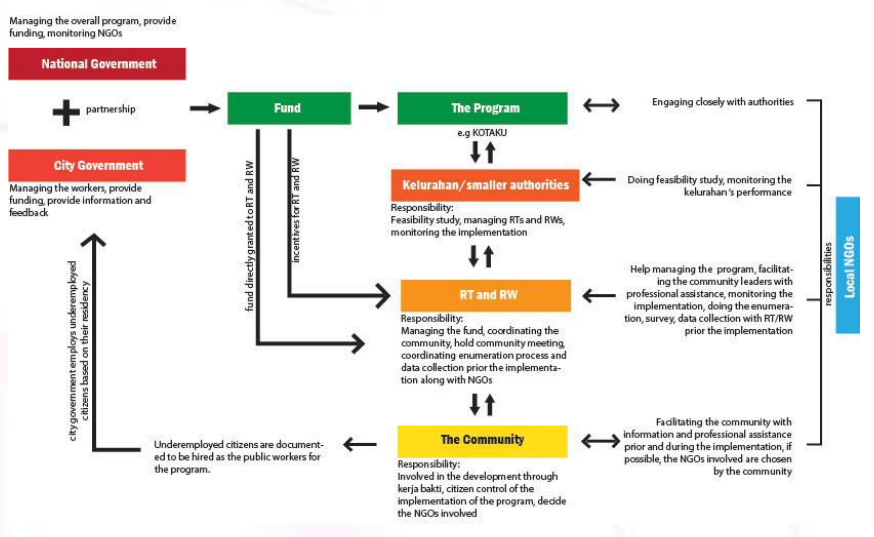

Figure 6 Recommedation Scheme

According to the analysis, there are several suggestions and schemes (see Fig. 6) that can be applied to future Kampung Kota improvement plans.

- Maximizing social capital in informal activities as a platform to increase the public engagement

Kampung Kota community has a high social capital and network; these aspects are the strengths that can increase the community engagement in the development in Kampung Kota. Not only sharing announcements by notification letter, but also putting up flyers in warung and Mosque, as those places are the most popular hotspot for the people to gather. It could result better by escalating the role of informal community organizations (e.g., pengajian groups) as a communication platform. Moreover, involving the community as early as possible makes them enlightened and have expectations about the programs. However, it should be noted that the information provided should be presented in a way that is easy to understand. The involvement of local NGOs and 
community leaders will also be helpful because they are familiar with the area

- Improving coordination and communication between authorities and community.

There is clear evidence that authorities lack coordination between each other, which makes the programs ineffective and should be addressed further. The proposed solution is a cooperative plan between the state, city and local government, which is not only beneficial to the program implementation, but also to co-fund the program. Partnerships between the authorities, government agencies, and other organizations have proven effective in many slum improvement programs, such as in Uganda (Macau et al., 2012) and India (Arputham, 2012). In addition, Kelurahan can also give a bigger impact to review the $R T / R W$ funding proposal in ensuring the programs delivery.

- Empowering the community by employing community members

Because many men of Mekarjaya are underemployed, it would be beneficial to adopt the PIPPK employment scheme to increase job opportunities. They could be employed based on their residency and managed by the municipal government. Kampung Kota residents who are interested could enlist to work in a variety of jobs for Kampung improvement initiatives. It would allow people to not only work and be paid, but also to participate in the development of their own neighborhood.

- Enhancing the role of NGOs and Neighbourhood Units $(R T / R W)$

In the on-going KOTAKU program, the local NGOs held a major part in presenting the program to the community. However, it has been identified that there was no clear coordination between the responsible agency, $R T / R W$, and Kelurahan in the current process. $R T / R W$ as the unit which was closest to the residents should get involved more actively to represent the community. If coordination can be done effectively, NGOs can provide $R T / R W$ with professional services (such as mediation, and technical consultancy) and follow many other slum improvement programs
(UN-Habitat, 2003; Archer et al., 2012; Hooper and Orlando) ,2012)

\section{- Integrated Plan}

Although the provisions of programs like $P I P P K$ and PNPM aim to solve the ongoing problems surrounding slums, they are often more reactive than proactive in improving Kampung Kota, and seem to treat the programs as a separate treatment from the overall city development plan. In the future, it is important to incorporate the development of Kampung Kota into the comprehensive prograns together with the urban planning plan (UN-Habitat, 2003). Not only are they important to the urban structure (Silas, 1989), they must also include Kampung Kota to ensure the social inclusiveness of the city's urban planning framework.

\section{Conclusion}

The development of improving the Kampung Kota condition is crucial, especially for the local community. Therefore, it is important to actively involve the community and work together to create better living conditions in Kampung Kota. Community Participation The development of Mekarjaya Kampung Kota shows that; although it was not done properly; it has room for improvement, especially considering the close relationship and the huge social capital within the community to empower the community. Strong social culture can help the betterment of Kampung Kota Development through enhancing residents' sense of belonging and the communication system that has been there to begin with. Therefore, the existing social culture can be utilized as a strong engagement tools. With an integrated plan and programs that brings government agencies and authorities on various level, the local NGOs, and the community members; it would help eradicate the problems arose from previous development programs.

\section{Acknowledgments}

The research was a part of the completion of Master of Urban Planning program in University of Technology Sydney in 2018 which the Author was enrolled in. The Author also would like to thank to all respondents and the Local Government that had help in 
providing the data and information. Utmost gratitude would also be given to Franklin Obeng-Odoom, Ph.D and Gabriela Quintana Vigiola, Ph.D for the advices and supervision upon conducting this research.

\section{References}

Archer, D., Luansang, C. and Boonmahathanakorn, S., 2012. Facilitating community mapping and planning for citywide upgrading: the role of community architects. Environment and Urbanization, 24(1), pp.115-129.

Arnstein, S., 1969. A Ladder of Citizen Participation. Journal of the American Institute of Planners, 35(4), pp.216-224.

Arputham, J., 2012. How community-based enumerations started and developed in India. Environment and Urbanization, 24(1), pp.27-30.

Davidoff, P., 1965. Advocacy and pluralism in planning. Journal of the American Institute of Planners, 31(4), pp.331-338.

Davies, R., 2010. community Engagement in Planning. Planning News, 36(7), p.18.

Direktorat Jenderal Cipta Karya (Ditjen Cipta Karya), 2017., Sekilas Informasi Program Kota Tanpa Kumuh (KOTAKU)., [online] available at: http://kotaku.pu.go.id/pustakadetil.asp?m $\mathrm{id}=483 \&$ catid $=5 \&$ [accessed 8 September 217]

Funo, S., Yamamoto, N. and Silas, J., 2002. Typology of kampung houses and their transformation process. Journal of Asian architecture and building engineering, 1(2), pp.2_193-200.

Fox, S., 2014. The political economy of slums: Theory and evidence from SubSaharan Africa. World Development, 54, pp.191-203.

Gilbert, A., 2007. The return of the slum: does language matter?. International Journal of Urban and Regional Research, 31(4), pp.697-713.

Habitat, U.N., 2003. Global Report on Human Settlements 2003: The Challenge of Slums. London: Earthscan.

Handayani, S., 2008. Partisipasi Masyarakat Kampung Kota untuk Meningkatkan Kualitas Lingkungan Perkotaan. Disertasi. Program Pascasarjana. Institut Pertanian Bogor.

Hooper, M. and Ortolano, L., 2012. Motivations for slum dweller social movement participation in urban Africa: a study of mobilization in Kurasini, Dar es Salaam. Environment and Urbanization, 24(1), pp.99-114.

IAP2., 2015., Quality Assurance Standard. [online] IAP2 Australasia. Available at: https://www.iap2.org.au/Tenant/C00000 04/00000001/files/IAP2_Quality_Assura nce_Standard 2015.pdf [Accessed 12 Nov. 2017].

Kawamura, K., 2011. Consensus and democracy in Indonesia: MusyawarahMufakat revisited.

Kustiwan, I., \& Ramadhan, A. (2019). Strategi Peningkatan Kualitas Lingkungan Kampung-Kota dalam Rangka Pembangunan Kota yang Inklusif dan Berkelanjutan: Pembelajaran dari Kasus Kota Bandung. Journal of Regional and Rural Development Planning (Jurnal Perencanaan Pembangunan Wilayah Dan Perdesaan), 3(1), 64-84.

Maslow, A.H., 1943. A theory of human motivation. Psychological review, 50(4), p.370.

Nasir, S. and Rosenthal, D., 2009. The lorong as a risk environment: Drug use and gangs among young men in the slums of Makassar, Indonesia. Contemporary Drug Problems, 36(1-2), pp.193-215.

Nastiti, A., Muntalif, B.S., Roosmini, D., Sudradjat, A., Meijerink, S.V. and Smits, A.J.M., 2017. Coping with poor water supply in peri-urban Bandung, Indonesia: Towards a framework for understanding risks and aversion behaviours. Environment and Urbanization, 29(1), pp.69-88.

Njoh, A.J., 2015. An OLS analysis of the impact of colonialism on inter-country differentials in slum incidence in Africa. Cities, 44, pp.104-111.

P2KP., 2017., Profil Slum. [online] P2KP. Available

at: http://sim.p2kp.org/p2kp/report/profil_ku muh.php?kode=3273 [Accessed $31 \bar{J} u l$. 2017].

Permana, A. Y., Susanti, I., \& Wijaya, K. (2019). Kerentanan Bahaya Kebakaran di Kawasan Kampung Kota. Kasus: Kawasan Balubur Tamansari Kota Bandung. Jurnal Arsitektur ZONASI, 2(1), 32-45.

Peters, R., 2009. The assault on occupancy in Surabaya: legible and illegible landscapes 
in a city of passage. Development and Change, 40(5), pp.903-925.

Peters, R., 2010, The Wheels of Misfortune: The Street and Cycles of Displacement in Surabaya, Indonesia. Journal of Contemporary Asia, 40(4), pp.568-588.

Peters, R., 2013, Surabaya, 1945-2010; Neighbourhood, State and Indonesia's City of Struggle, NUS Press: Singapore.

Reerink, G., 2011. Tenure security for Indonesia's urban poor: A socio-legal study on land, decentralisation, and the rule of law in Bandung. Leiden University Press.

Samba, R.D., de Pee, S., Kraemer, K., Sun, K., Thorne-Lyman, A., Moench-Pfanner, R., Sari, M., Akhter, N. and Bloem, M.W., 2009. Purchase of drinking water is associated with increased child morbidity and mortality among urban slum-dwelling families in Indonesia. International Journal of Hygiene and Environmental Health, 212(4), pp.387397.

Seputar Indonesia., 2013., Bandung Masih Miliki 29 Kawasan Kumuh. [online] Available at: https://economy.okezone.com/read/2017/ 02/15/470/1618737/bandung-masihmiliki-29-kawasan-kumuh [Accessed 8 Aug. 2017].

Silas, J., 1992. Government-community partnerships in Kampung improvement programmes in Surabaya. Environment and Urbanization, 4(2), pp.33-41.

Silas, J., 1989. Marginal settlements in surabaya, Indonesia: problem or potential? Environment and Urbanization, 1(2), pp.60-70

Solikhah, N., \& Fatimah, T. (2020). Kampung hijau pada kampung kota (studi kasus: Kampung Tanjung Gedong RT. 05/RW. 08, Jakarta Barat). Jurnal Bakti Masyarakat Indonesia, 3(1).

Turner, John FC., 1976 Housing by People., London, Whitstable Litho Ltd. Kent.

Widjaja, P., 2013. Kampung Kota Bandung., Graha Ilmu: Yogyakarta

Yin, R.K., 2003. Case study research: Design and methods. Thousands Oaks. Sage. Young, LC and Wilkinson, IR (1989). The role of trust and co-operation in marketing channels: a preliminary study. European Journal of Marketing, 23(2), pp.109-122. 